Colum McCann - Anda Bukvić Pažin

\title{
Sve u ovoj zemlji mora
}

Nadošla je ljetna bujica i naša je teretna kobila zapela u rijeci. Rijeka je pljuskala o kamenje i zvuk je bio kao kad brave škljocaju. Bilo je vrijeme silaže i voda je mirisala po travi. Teretna kobila, očeva ljubimica, zašla je u rijeku, da ponjuši možda, pa zapela, ni makac, prednja noga zaglavila među kamenjem. Otac ju je našao i povikao Katie! nadglasavajući se s hukom kiše. Ja sam bila u staji, isplazila jezik da dočekam kapi iz rupe na krovu. Istrčala sam pored kuće u polje. U rijeci je kobila sumanuto kolačila oči kroz kišu, možda me prepoznala. Otac se kretao sporo i preplašeno kao da gazi kroz dubok snijeg, osim što snijega nije bilo, bujica samo, a otac se bojao vode, bojao se oduvijek. Viknuo je Na onaj tamo kamen, mala. Dodao mi je uže s kopčom za povodac i znala sam što mi je činiti. Od oca sam viša još od zadnjeg rođendana, petnaestoga. Raširila sam se kao ljubav i stavila jednu nogu na kamen posred rijeke, rukom uhvatila granu iznad njega i odbacila se preko bujice.

Iza mene otac je rekao Ej, sad polako samo. Voda je tekla topla i brza i pridržavala sam se za granu, ali sagnula sam se s kamena i zakvačila uže za povodac krasne teretne kobile.

Stabla su se šaptom povijala prema rijeci i duge su im se sjene nadvile nad vodom, a kobila je trznula brzo i naglo i osjetila sam da će biti smrti, ali povukla sam uže uvis da joj zadržim vrat iznad vode, jedvice.

Otac je grmio Drž' taj konop curo, ne puštaj! i vidjela sam mu zube čvrsto stisnute i oči razrogačene i sve velike vene na njegovom vratu, kao kad obilazi grabe po našoj farmi, tolike krave, živice, plotove. Otac je stalno u strahu otkad je izgubio mamu i Fiachru i sad još to s kobilom, njegovom omiljenom, velikom belgijankom koja je nekoć davno plužila polja.

Rijeka se rascijepila kod kamena, poskočila visoko i pošpricala mi noge i haljinu. Ali ja nisam ispuštala uže, držala sam ga kao što otac zna držati zadnji nepopušeni Sweet Afton u vrijeme ručka, prije molitve. Otac je vikao Tako drži mala, dobar! Gledao je u vodu kao da je ondje mama, kao da je i Fiachra s njom pa uhvatio zraka i nestao u rijeci da teretnoj kobili oslobodi kopito, a ja 
sam zajaukala prema nebu što sam tako dugo sama. Čvrsto se držao za korijen stabla, ali tijelo mu je iščezlo pod brzom smeđom vodom.

Noć je užgala zvijezde. Bile su gore među granama. I u njima je prskala rijeka.

Otac je izronio hvatajući zrak, oči konjski sumanute, kapu mu je odnijela rijeka. Uže mi je skakalo u rukama i peklo kao ploča na štednjaku, a on je vikao Drži, mala, za Boga miloga, molim te drži! Otac je opet nestao u rijeci, ali izronio je brzo, pluća više nisu mogla pod vodom. Stajao je u rijeci hvatajući se korijena, voda mu je zapljuskivala ramena, i bio je tužan dok je gledao teretnu kobilu kako se utapa pa sam ja povukla povodac jače i kobila je vrisnula jako, i opet podigla glavu iznad vode.

Još jednom, rekao je otac glasom tužnim kao onda, nekoć davno, nad maminim i Fiachrinim lijesom.

Otac je zaronio i ostao pod vodom dulje nego što traju jučer i prekjučer skupa, a onda su se pojavili neki farovi, prosuli svoje snopove po cesti. Svjetla su od kiše napravila platno, skroz visoko gore, i pobacala sjenke po živicama i jarcima. Očeva je glava izletjela iz vode i disao je teško pa nije vidio svjetla. Prsa su mu se širila i poskakivala. Pogledao je kobilu pa mene. Pokazala sam prema cesti, a on se okrenuo u bujici i zagledao se. I osmjehnuo se, pomislivši možda da je to Mack Devlin sa svojim mljekarskim kamionetom ili Molly na povratku kući s posla, ili netko tko mu je došao pomoći da spasi omiljenu kobilu. Upro se o korijen stabla, izverao iz rijeke pa stao na obalu i digao ruke u zrak kao da maše, vičući Amo, amo, ej!

Očeva je majica bila mokra pod kombinezonom i sasvim bijela kad su je farovi obasjali. Svjetla su se primakla i u tom smo bljesku čuli povike, a onda su i glasovi postali jasniji. Zvučali su kao da su progutali nešto što ja nikad nisam.

Pogledala sam oca i on je pogledao mene, s najčudnijim izrazom lica odjednom, kao da je izgubljen, kao da je udaren, kao da je on kapa koju nosi rijeka, kao da je osamljeno veliko stablo očajno za šumom. Oni su doviknuli Hej stari, šta je? na svoj čudan način, i otac je rekao Ništa i glava mu je potonula baš duboko na grudi i pogledao je preko rijeke prema meni, i ja mislim da mi 
je govorio Pusti uže curo, ali ja nisam. I dalje sam zatezala, držeći kobilin vrat iznad vode, i cijelo vrijeme otac je govorio, ali ipak nije rekao Pusti konop, molim te, Katie, pusti ga, neka se utopi.

Pohitali su ravno kroz živicu ne mareći za uniforme i čula sam kako im trnje para po jaknama. Jedan je u trku skinuo kacigu i kosa mu je bila boje zimskog leda. Drugi je imao brkove poput busenastih travki, a treći ožiljak na obrazu nalik srpastoj oštrici očeva noža.

Oštrica se prvi dokopao ruba rijeke, puška mu je lupila o bok kad je doskočio na kamen na kojemu sam ja držala povodac. Dobro je, malena, rekao mi je, a ruka mu je bila sva kišna na mojim leđima. Primio je povodac i dovikivao ostalim vojnicima što će raditi, kamo stati. Ne ispuštajući povodac, predao me Travki, koji me uzeo za ruku i sigurno doveo do obale. Sad su bila šestorica, same puške i kacige. Otac se nije micao. I dalje nije skidao pogled s rijeke, možda je ugledao mamu i Fiachru kako ga promatraju iz vode.

Jedan mu se vojnik obratio, glasno i brzo, ali otac je bio poput lutke iz izloga u Derryju, i vojnik je digao obje ruke u zrak, okrenuo se pa udaljio kroz kišu, obilno pljunuvši u vjetar.

Oštrica je uspješno balansirao s povodcem, nije se čak ni uhvatio za granu iznad sebe.

Ledenokosi je skidao čizme i pušku i majicu i uopće nije izgledao kao dečki iz grada koji dolaze u staju po ljubav, nije izgledao kao otac kad bez majice kosi sijeno, ne, nikomu nije bio nalik; bio je vrlo mršav i snažan s rebrima kakva konj katkad ima nakon cijeloga dana u polju. Nije zaronio onako kako sam, čini mi se, očekivala da hoće, samo je zagazio u vodu jako sporo, uopće se ne praveći važan, i počeo se probijati, ruke visoko u zraku, propadajući sve više. Ali rijeka je postala preduboka i Oštrica mu je dovikivao s kamena, čulo se Ostani na ravnome, Stevie, ne ulazi dublje.

A Stevie je Oštrici pokazao palac gore pa nestao pod vodom, zadnji je bio udarac nogom o površinu.

Travka je stajao pored mene i prebacio mi Steviejevu jaknu preko ramena da me ugrije, ali odmah je prišao otac i odgurnuo ga. Gurnuo ga je snažno. Bio je manji od Travke, ali Travka je poletio prema stablu i udario u njega. Travka je udahnuo duboko i prodorno ga pogledao. Otac je rekao Okani je se, to je dijete! Pokrila sam lice od srama kao u školi kad su me u razredu stavili u posebnu klupu veću od ostalih, a ne onu drvenu s pločom što se diže i spušta. Samo što ja više ne 
idem u školu nakon onoga s mamom i Fiachrom. Obuzeo me sram poput srama toga dana u školi pa sam pokrila lice i virila kroz prste.

Otac je Travku šibao pogledom. I Travka je dugo zurio u oca pa onda odmahnuo glavom i otišao do riječne obale gdje je Stevie još bio pod vodom.

Otac je držao ruke na mojim ramenima i grijao me i rekao Bit će sve u redu, mala moja, ali ja sam mislila samo na Stevieja i koliko dugo je pod vodom. Oštrica je vikao na sav glas i gledao dolje prema rijeci, a ja sam podigla pogled i ugledala veliki vojni kamion kako probija ogradu, i u živici se rastvorila velika rupa, a otac je vrisnuo Ne!

Na kamionu su upalili reflektore i obasjali cijelu rijeku. Otac je opet vrisnuo Ne! ali ušutio je kad ga je jedan od vojnika sasjekao pogledom. Konj ili prokleta živica, biraj stari!

Otac je sjeo na obalu i rekao Sjedni, Katie, i u njegovu sam glasu čula više tuge nego na maminom i Fiachrinim odru, više tuge nego dan nakon što ih je udario vojni kamion u blizini klanca, više tuge nego onda kad je sudac rekao Nitko nije kriv, bila je to tragedija, više tuge čak i nego toga dana, i svih ostalih dana nakon toga.

Gadovi, prošaptao je otac, gadovi, i zagrlio me i sjedio i gledao dok Stevie nije izronio iz vode, plivajući protiv struje da ostane u mjestu. Doviknuo je Oštrici Noga je zapela, a onda Pokušat ću izvući kopito. Stevie je uzeo četiri duboka udaha i Oštrica je vukao povodac i teretna je kobila njištala kako nikad nisam čula da konj njišti, prije ni poslije. Otac je šutio, a ja sam poželjela da sam natrag u staji sama i da dočekujem kapi kiše na jeziku. Bila sam u Steviejevoj jakni, ali cvokotala sam mokra i promrzla i preplašena zato što će Stevie i teretna kobila umrijeti jer sve u ovoj zemlji mora.

Otac voli čaj bez vrećica, onako kako ga je radila mama pa ga ja pripremam na poseban način: stavim hladnu vodu u kuhalo i to isključivo hladnu, onda čekam da zakuha pa stavim proključalu vodu u čajnik i razlijem je malo, dok se dno ne ugrije. Onda unutra stavim listiće čaja, ne vrećice, onda proključalu vodu pa sve promiješam jako polako, pokrijem čajnik i pustim da odstoji na štednjaku pet minuta, pazeći da plamen ne bude previsok, da prekrivač na čajniku ne uhvati 
plamen i izgori. Onda ulijem mlijeko u šalice pa čaj, šećer na samome kraju, i sve pažljivo promiješam da se poveže.

Moja je procedura oko čaja vojnicima izmamila osmijeh, čak i Stevieju, kojemu je krv liptala iz glave, ondje gdje ga je kobila udarila iznad oka. Otac je problijedio kad se Stevie osmjehnuo, ali Stevie je bio jako pristojan. Uzeo je ručnik koji sam mu pružila, rekao da ne želi zakrvariti stolac. Osmjehnuo mi se dvaput kad sam povirila iz kuhinje i pokazao jedan prst, što znači Jedna šećera, molim i veliku nulu od prstiju za Mlijeko ne, hvala. Nešto krvi sušilo mu se u kosi i oči su mu bile vedre kao što bi nebo trebalo biti, i osjetila sam kako mi trbuh tone i postaje nalik ljubavi u staji, i poslao mi je osmijeh broj tri.

Svi su bili zadovoljni što su spasili život, makar i konjski, možda čak i otac, ali otac je šutio u kutu. Ljutio se na mene što sam vojnike pozvala na čaj i brada mu je bila na prsima, a pod nogama lokva. Svi su se brisali ručnicima osim oca, jer ručnika nije bilo dovoljno.

Travka je sjeo u fotelju i rekao Dobro da imaš lampe za grijanje, gazda.

Otac je samo kimnuo.

Kako je bilo pod vodom, Stevie? upitao je Travka.

Mokro, odgovorio je Stevie i svi su se nasmijali, ali otac ne. Zurio je u Stevieja, a onda svrnuo pogled.

Dnevna je soba vječno mračna i otac je smrknut, ali sad je bilo svjetlije. Sviđalo mi se zelenilo uniformi, čak i crvenilo Steviejeve krvi. A Stevieja je od udarca kobile sigurno jako boljela glava. Ostali su vojnici govorili da bi možda Stevieja trebali kamionom odvesti ravno u bolnicu umjesto da se tu suše, bolje bi bilo da dobije par šavova umjesto čaja, a i poslije mogu navratiti da vide kako je kobila i je li preživjela pod lampama. Ali Stevie je rekao Dobro sam, momci, samo ogrebotina, nema što ne bih dao za šalicu čaja.

Čaj je dugo odstajao pa je bio fin i imali smo kekse za posebne goste, otišla sam po njih u smočnicu. Zagrizla sam jedan da provjerim jesu li svježi i iznijela pladanj.

Kihnula sam, ali baš sam pazila da ne kihnem u pladanj, da se vidi da sam pristojna kao Stevie. 
Stevie je rekao Nazdravlje na svoj smiješni, smiješni način i svi smo šutjeli i pijuckali čaj, ali ja sam opet kihnula tri četiri pet puta i Oštrica je rekao Trebala bi presvući tu mokru odjeću, mala.

Otac je tresnuo šalicu o tanjurić i zavladala je tišina.

Svi, čak i vojnici gledali su u pod i sat je na kaminu otkucavao i mamina slika gledala nas je sa zida i Fiachra kad je igrao nogomet i vojnici ih nisu vidjeli, ali otac jest. Duga tišina bivala je dulja i dulja sve dok otac nije zazvao, Dođi amo, Katie, i posadio me uz prozor pa posegnuo za dugim zastorom. Okrenuo me, umotao u njega i primio mi kosu pa počeo trljati, ne nježno već čvrsto. Otac je dobar, htio mi je samo osušiti kosu jer sam cvokotala, čak i u Steviejevoj jakni. Ispod zastora vidjela sam vojnike, Stevieja najbolje. Otpio je svoj čaj i osmjehnuo mi se i otac se nakašljao baš glasno i sat je kucao još malo dok Oštrica nije rekao Evo, gazda, osuši je mojim ručnikom.

Otac je rekao $\mathrm{Ne}$, hvala.

Oštrica je rekao Uzmi samo, gazda pa zgužvao ručnik i spremio se da ga baci.

Otac je rekao $\mathrm{Ne!}$

Stevie je rekao Polako.

Polako? ponovio je Oštrica.

Možda da sad svi odete, rekao je otac.

Oštrica je promijenio izraz lica i bacio ručnik na zemlju do očevih nogu, i njegovi su se obrazi naduli i teško je disao i rekao I to nam je jebeno hvala, gazda?

Oštrica je sad bio na nogama i upirao je prstom u oca, i svjetlo se odbijalo o njegove dobro ulaštene čizme i lice mu se trzalo pa je ožiljak izgledao kao da siječe napola. Travka i Stevie ustali su sa stolaca i pridržavali Oštricu, ali Oštrica je nastavljao Riskiramo jebene živote da spasimo tvog jebenog konja i to nam je hvala, ha?

Otac me držao jako čvrsto umotanu u zastor i izgledao je uplašen i malen i drhturav. Oštrica je urlao strašno, crven i izobličen u licu. Stevie ga je držao. Steviejevo lice bilo je smrknuto i tužno i znala sam da zna jer je stalno pogledavao mamu i Fiachru na kaminu pored kuckavog sata. Stevie je odvukao Oštricu iz boravka i na kuhinjskim ga je vratima pustio. Oštrica se okrenuo preko 
Steviejeva ramena još jedan, zadnji put i pogledao oca sasvim smrknuta lica, ali Stevie ga je opet zgrabio i rekao Zaboravi, stari.

Stevie je izveo Oštricu van kroz kuhinju pa u dvorište prema vojnom kamionu i vani je još pljuštala kiša i onda je u boravku utihnulo sve osim sata.

Čula sam zvuk motora kamiona.

Otac se odmaknuo od mene i spustio glavu na kamin pored fotografija. Ja sam ostala uz prozor i dalje u Steviejevoj jakni koju je Stevie zaboravio i po koju se još nije vratio.

Gledala sam kamion kako silazi cestom i crvena svjetla na zelenoj kapiji kad je stao pa se priključio na glavnu cestu ondje pored mjesta gdje su teretnu kobilu izvukli iz rijeke. Nakon toga nisam čula ništa, jedino kako mukli zvukovi kreću iz očeva grla, i nisam odvratila pogled od prozora jer znala sam da će biti ljut što ga gledam. Otac je grcao i šmrcao, možda je zaboravio da sam tu. Ušlo je ravno u njega i izlazilo u ridanju kakvo nikad prije nisam čula. I dalje sam šutjela, ali otac se tresao strahovito. Izvadio je rupčić i odmaknuo se od kamina. Nisam ga gledala jer znala sam da će ga biti sram što plače.

Vojni je kamion gotovo nestao iz vida, crvena svjetla na živicama.

Čula sam tresak vrata dnevnog boravka, onda kuhinjskih vrata, pa vrata smočnice gdje otac drži svoju lovačku pušku, onda ulaznih vrata, i čula zvuk otponca i njega kako još plače i ide sve dalje i dalje sve dok plač nije utihnuo, i sigurno je bio u dvorištu i stajao na kiši.

Sat na kaminu zvučao je jako glasno, a tako je i kiša, tako i moje disanje, i pogledala sam kroz prozor.

Na glavnoj cesti nije bilo žive duše i vojnici su zamakli iza ugla kad sam čula taj zvuk; nije bilo kao metak, više kao prasak jedan dva tri.

Sat je i dalje kucao.

Kucao je, kucao i kucao.

Zastor je bio mokar, ali čvrsto sam ga privila uza se. Prestrašila sam se, nisam se mogla maknuti. Čekala sam, činilo se, vječnost. 
Kad je otac ušao, znala sam što je bilo. Lice mu je bilo kao isklesano u kamenu i više nije plakao i nije me čak ni pogledao, samo je otišao i sjeo u fotelju. Posegnuo je za šalicom koja je zazvečala na tanjuriću pa ju je opet odložio, zakopao lice u ruke i ostao tako. Otkucaja više nisam bila svjesna i sve je bilo tiho posvuda u svijetu, i zadržavala sam zastor kao i zvuk metaka što prodiru u tijelo kobile, njegove omiljene, u staji, jedan dva tri, i stajala sam uz prozor u Steviejevoj jakni i gledala i čekala i još je vani pljuštala kiša jedan dva tri i mislila sam, oh, premalo je to nebo za toliko kiše.

\section{(c) (i) (9)}

Creative Commons Attribution-NonCommercial-NoDerivatives 4.0 International License 